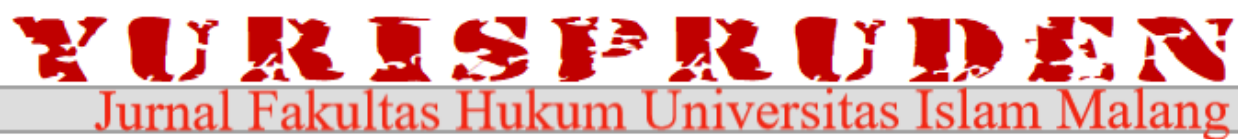 \\ Volume 5, Nomor 1, Januari 2022.
}

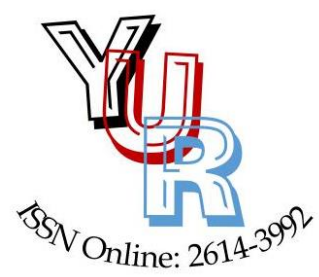

Editorial Office : Faculty of Law, Univeritas Islam Malang.

Jl. Mayjen Haryono No.193, Dinoyo, Kec. Lowokwaru, Malang, Provinsi Jawa Timur, 65144.

Phone : :(0341) 551932 / 551822 / (0341) 552249

E-mail : yurispruden@unisma.ac.id

Website $\quad:$ http://riset.unisma.ac.id/index.php/yur/index

\section{Keabsahan Jual Beli Di Bawah Tangan Tanah Transmigrasi Di Kabupaten Mamuju Tengah}

\section{Muh. Galil Gibran, Dian Aries Mujiburohman, Rofiq Laksamana}

Sekolah Tinggi Pertanahan Nasional

Jl. Tata Bhumi No. 5, Banyuraden, Sleman, Yogyakarta, 55293

Email: esamujiburohman@stpn.ac.id

Article

Article History

Received: May 31, 2021;

Reviewed: Jun 21, 2021;

Accepted: Jun 22, 2021;

Published: Jan 20, 2022;

DOI:

10.33474/yur.v5i1.8897

\section{Abstract}

The government provides land for the implementation of transmigration. The land is granted with the status of property rights on the condition that it cannot be traded for 20 (twenty) years. However, many transmigrants do not feel at home and choose to return to their original areas, by selling the transmigration land to other parties before 20 years. The sale and purchase of transmigration land is carried out under the hands without a deed from PPAT. So the problem studied is the legality of buying and selling under the hands and how to resolve it to register land at the Land Office if there is no PPAT deed, because the seller's whereabouts are unknown. This study uses empirical normative legal research methods with primary data sources through interviews. The results of the study show that buying and selling under the hands according to customary law is legal as long as it meets the requirements, namely clear and cash, but buying and selling under the hands without a deed of sale and purchase made by PPAT cannot be registered at the Land Office.

Keywords: Transaction, Unregistered, Transmigration Land, Land Registered.

Abstrak
Pemerintah menyediakan tanah bagi penyelenggaraan
transmigrasi. Tanah tersebut diberikan dengan status hak milik
dengan ketentuan tidak dapat dijual belikan selama 20 (dua puluh)
tahun. Namun banyak transmigran yang tidak betah dan memilih
untuk kembali ke daerah asalnya, dengan cara menjual tanah
transmigrasi tersebut kepada pihak lain sebelum 20 tahun. Jual beli
tanah transmigrasi yang dilakukan di bawah tangan tanpa akta dari
PPAT. Maka masalah yang dikaji adalah keabsahan jual beli di
bawah tangan dan bagaimana penyelesaiannya untuk
mendaftarkan tanah di Kantor Pertanahan bila tidak ada akta
PPAT, disebabkan pihak penjual tidak diketahui keberadaannya.


Penelitian ini menggunakan metode penelitian hukum normatif empiris dengan sumber data primer melalui wawancara. Hasil kajian menunjukan jual beli di bawah tangan menurut hukum adat adalah sah sepanjang memenuhi syarat yaitu terang dan tunai, namun jual beli dibawah tangan tanpa adanya akta jual beli yang dibuat oleh PPAT tidak dapat didaftarkan di Kantor Pertanahan.

Kata Kunci: Jual Beli, Dibawah Tangan, Tanah Transmigrasi, Pendaftaran Tanah.

PENDAHULUAN

Tanah mempunyai sifat unik karena persediaannya selalu tetap, artinya tanah tidak dapat diproduksi maupun dikurangi dan lokasinya tidak dapat digeser atau dipindahkan. Maka permasalahan apapun yang muncul terkait pertanahan akan berimplikasi dengan seluruh aspek kehidupan yang saling berkaitan, bagi masyarakat tanah memiliki makna multidimensional. ${ }^{1}$ Tanah yang selama ini menjadi sumber kehidupan dan faktor utama pendukung kebutuhan dan kesejahteraan bagi masyarakat.

Kebutuhan akan tanah dewasa ini meningkat sejalan dengan bertambahnya jumlah penduduk dan meningkatnya kebutuhan lain yang berkaitan dengan tanah. Tanah tidak saja sebagai tempat bermukim, tempat untuk bertani tetapi juga dipakai sebagai jaminan mendapatkan pinjaman di bank, untuk keperluan jual beli, dan sewa menyewa. Tanah yang merupakan sumber kehidupan seharusnya dapat diberikan kepada rakyat secara merata. ${ }^{2}$ Melalui program transmigrasi yang dilaksanakan oleh pemerintah dapat mengurangi kemiskinan dan terwujudnya pemerataan kesejahteraan bagi seluruh masyarakat Indonesia.

Pengaturan tentang transmigrasi diatur dalam Undang Undang Nomor 3 Tahun 1972, kemudian diganti dengan Undang Undang Nomor 15 Tahun 1997 tentang Ketransmigrasian, dan diubah dengan Undang Undang Nomor 29 Tahun 2009 tentang Perubahan atas Undang Undang Nomor 15 Tahun 1997.

Sebagai peraturan pelaksana diatur dalam Peraturan Pemerintah Nomor 42 tahun 1973 tentang penyelenggaraan transmigrasi. Pada prinsipnya tanah transmigrasi tidak dapat dipindahtangankan, kecuali transmigran meninggal dunia, setelah memiliki hak sekurang-kurangnya selama 20 (dua puluh) tahun dan transmigran Pegawai Negeri yang dialih tugaskan. Pemindahtanganan di luar ketentuan tersebut, hak milik menjadi hapus dan tanahnya kembali kepada pemegang Hak

\footnotetext{
1 Dian Aries Mujiburohman, (April, 2018), Menyoal Penafsiran Tanah Terlantar, Jurnal Yudisial, Volume 11 Nomor 1. Hlm. 1-2.

2 S.P Florianus Sangsun, (2008), Tata Cara Mengurus Sertipikat Tanah, Jakarta; Visi Media. Hlm. 1.
} 
Pengelolaan dan diberikan kepada transmigran pengganti.

Program transmigrasi sangat penting untuk mengatasi permasalahan kepadatan penduduk dan meningkatkan kesejahteraan, maka sudah selayaknya program ini dipertahankan dan dikembangkan. ${ }^{3}$ Namun pada kenyataannya banyak para transmigran yang tidak betah dan memilih untuk kembali ke daerah asalnya, dengan cara menjual tanah transmigrasi tersebut kepada pihak lain. Meskipun telah diatur larangan bahwa tanah yang diberikan kepada transmigran tidak dapat dipindahtangankan, kecuali telah dimiliki paling singkat selama 20 (dua puluh) tahun sejak penempatan. ${ }^{4}$

Persoalan lainya adalah penjualan tanah transmigrasi hanya dilakukan dengan cara lisan, kuitansi dan surat keterangan jual beli yang di ditanda tangani masing-masing pihak, kemudian disaksikan oleh beberapa saksi dan diketahui oleh Kepala Desa setempat, tidak melalui pembuatan akta jual beli di hadapan Pejabat Pembuat Akta Tanah (PPAT). Hal ini mengakibatkan peralihan hak atas tanah tidak dapat didaftarkan di Kantor Pertanahan. Disisi lain ketika Pembeli akan melakukan balik nama sertipikat penjual sudah tidak diketahui keberadaannya karena sudah kembali ke daerah asalnya.
Kabupaten Mamuju Tengah yang dibentuk berdasarkan Undang Undang No. 4 Tahun 2013 tentang Pembentukan Kabupaten Mamuju Tengah di Provinsi Sulawesi Barat. Merupakan Kabupaten pemekaran dari Kabupaten Kota Mamuju sebagai Kabupaten induk. Salah satu kecamatannya yaitu Kecamatan Budong-Budong terdapat sedikitnya empat Unit Permukiman Transmigrasi (UPT) yaitu Tinali I, Tinali II, Salogatta, dan Pontanakayang, dengan tahun penempatan antara tahun 1984 sampai dengan 1987, dengan jumlah sekitar 4636 Kepala Keluarga.

Penelitian ini menggunakan metode penelitian hukum normatif empiris sebagai metode penelitian hukum mengenai pemberlakuan ketentuan hukum normatif (kodifikasi, undang-undang atau kontrak) secara in action pada setiap peristiwa hukum tertentu yang terjadi dalam masyarakat. Penelitian hukum normatif bertujuan untuk mengetahui keabsahan jual beli di bawah tangan tanah transmigrasi. Kemudian penelitian empiris digunakan untuk menganalisis bagaimana penyelesaian peralihan hak atas tanah di Kantor Pertanahan bila tidak ada akta PPAT, disebabkan pihak penjual tidak diketahui keberadaannya.

Data yang digunakan dalam penelitian ini adalah melalui penelitian kepustakaan dengan

\footnotetext{
3 WH. Legiani, Lestari RY., Haryono, (2018), Transmigrasi dan Pembangunan di Indonesia: Studi Deskriptif Sosiologi Kependudukan dan Pembangunan, Jurnal Hermeneutika, Volume 4, Nomor 1. Hlm. 25-35.

4 Pasal 31 peraturan Pemerintah Nomor 3 Tahun 2014 tentang Pelaksanaan Transmigrasi.
} 
menggunakan alat pengumpulan data studi dokumen dan data primer diperoleh melalui penelitian lapangan dengan menggunakan pedoman wawancara. Lokasi yang dipilih adalah Kabupaten Mamuju Tengah, dengan pertimbangan adanya praktik jual beli tanah di bawah tangan tanah transmigrasi yang kesulitan dalam proses peralihan/balik nama karena pemilik yang tertera dalam sertipikat tidak diketahui keberadaannya.

\section{PEMBAHASAN}

\section{Keabsahan Jual Beli di Bawah Tangan}

Peralihan suatu bidang tanah dapat terjadi dengan berbagai cara, salah satunya ialah melalui proses jual beli. Hayati menyatakan jual beli sebagai tindakan pemindahan barang yang dijual ke dalam kekuasaan dan pemilikan pembeli. Misalnya penjualan rumah atau tanah, penjual menyerahkan kepada pembeli baik secara nyata maupun secara yuridis dengan jalan melakukan akta jual beli untuk proses balik nama (overschrijving) dari nama penjual kepada nama pembeli umumnya terdapat pada penyerahan benda-benda tidak bergerak. ${ }^{5}$ Peralihan bisa disengaja oleh adanya perbuatan hukum seperti jual beli, baik secara adat maupun berdasar pada peraturan perundang-undangan yang berlaku.
Bila merujuk pada hukum adat dalam perbuatan jual beli unsur yang terpenting adalah terpenuhinya syarat terang dan tunai. Menurut Sumardjono syarat untuk sahnya jual beli tanah menurut hukum adat adalah terpenuhinya tiga unsur yaitu tunai, riil dan terang. ${ }^{6}$ Hal yang sama dinyatakan oleh Ridwan, dalam hukum adat jual beli tanah dikenal istilah bentuk jual lepas yaitu suatu penyerahan tanah kepada pihak lain (pembeli), dengan pembayaran harga tanah secara tunai, dimana hak milik atas tanah itu berpindah ke tangan pembeli untuk seterusnya. ${ }^{7}$ Lazimnya terdapat kebiasaan untuk melakukannya secara tertulis, yang ditandatangani sendiri oleh penjual, diketahui oleh kepala persekutuan serta turut ditandatangani oleh saksi-saksi yang diperlukan. ${ }^{8}$ Pada kenyataannya jual beli hak atas tanah secara adat masih menjadi alternatif yang dipilih oleh masyarakat di berbagai daerah terutama pada masyarakat yang jauh dari perkotaan, selain dirasa mudah dan efisien, jual beli secara adat juga dari segi biaya jauh lebih terjangkau.

Jual beli dalam hukum perdata diatur pada Pasal 1457, Pasal 1458, Pasal 1459 dan Pasal 1457 KUH Perdata mendefinisikan jual beli adalah suatu persetujuan, dengan mana

\footnotetext{
5 Nur Hayati, (2016), Peralihan Hak Dalam Jual Beli Hak Atas Tanah: Suatu Tinjauan Terhadap Perjanjian Jual Beli dalam Konsep Hukum Barat dan Hukum Adat dalam Kerangka Hukum Tanah Nasional, Lex Jurnalica, Volume 13, Nomor 3. Hlm. 283-287.

6 Maria SW. Sumardjono, (2001), Kebijakan Pertanahan Antara Regulasi dan Implementasi, Jakarta; Buku Kompas. Hlm. 119.

7 Ahmad Fauzie Ridwan, (1982), Hukum Tanah Adat, Jakarta; Dewaruci Press. Hlm. 38.

8 Ibid.
} 
yang mengikatkan dirinya untuk menyerahkan suatu kebendaan dan pihak yang lain untuk membayar harga yang telah dijanjikan. Titik persamaan antara hukum adat dengan hukum perdata dalam perihal jual beli ialah bahwa jual beli mengandung tujuan perekonomian yang tertentu yaitu memindahkan hak milik atas sesuatu barang dari seseorang tertentu kepada orang lain.

Pasal 1320 KUH Perdata merupakan instrumen pokok untuk menguji keabsahan perjanjian yang dibuat para pihak. Dalam pasal tersebut terdapat 4 (empat) syarat yang harus dipenuhi untuk sahnya suatu perjanjian, yaitu:

1. Kesepakatan kedua belah pihak, artinya kedua belah pihak setuju mengenai hal-hal pokok dalam perjanjian, timbulnya kehendak atau keinginan itu tidak didasarkan atas paksaan, kekhilafan, atau penipuan dari salah satu pihak.

2. Kecakapan, cakap dalam perbuatan hukum adalah setiap orang yang sudah dewasa dan sehat pikirannya.

3. Hal yang tertentu suatu hal yang menjadi objek perjanjian adalah pokok perjanjian. Artinya apa yang diperjanjikan hak dan kewajiban para pihak.

4. Sebab yang halal, isi dari perjanjian tersebut atau tujuan dari para pihak mengadakan sebuah perjanjian, yaitu memiliki dasar yang sah dan tidak

bertentangan dengan undang-undang, ketertiban umum dan kesusilaan.

Dalam pandangan hukum adat dan KUH Perdata telah terpenuhi unsur sahnya perbuatan jual beli namun status keabsahan jual beli tanah transmigrasi tanpa adanya akta otentik yang dibuat oleh PPAT mengakibatkan tidak dapat dilaksanakannya proses peralihan atas tanah tersebut. Hal ini ditegaskan dalam ketentuan Pasal 37 ayat (1) Peraturan Pemerintah Nomor 24 Tahun 1997 tentang Pendaftaran Tanah, yang menyatakan untuk mewujudkan adanya suatu kepastian hukum dalam setiap peralihan hak atas tanah setiap perjanjian yang bermaksud memindahkan hak atas tanah harus dibuktikan dengan suatu akta yang dibuat oleh PPAT.

Akta dikenal ada 2 (dua) jenis akta, yaitu akta autentik dan akta di bawah tangan. Akta autentik memiliki kekuatan bukti yang sempurna bagi kedua belah pihak, ahli warisnya, dan orang-orang yang mendapat hak darinya. ${ }^{9}$ Akta di bawah tangan diakui dalam KUH Perdata yaitu Pasal 1320 telah ditentukan syarat sahnya perjanjian. suatu akta yang tidak dibuat di hadapan PPAT adalah tetap sah sepanjang para pihak tetap sepakat dan memenuhi unsur-unsur dalam Pasal 1320 KUH Perdata. Fungsi akta ada 2 yaitu fungsi formal yang menentukan 
lengkapnya (bukan untuk sahnya), dan fungsi akta sebagai alat bukti di kemudian hari. ${ }^{10}$

Jual beli di bawah tangan di Kabupaten Mamuju Tengah Provinsi Sulawesi Barat, hal ini disebabkan karena: pertama, transaksi jual beli dilakukan sekitar tahun 1991 sampai dengan tahun 2003, saat itu wilayah Provinsi Sulawesi Barat belum terbentuk dan masih bergabung dengan wilayah Provinsi Sulawesi Selatan dengan ibu kota Makassar sebagai sentral Pemerintahan. ${ }^{11}$ Jarak yang terlampau sangat jauh membuat masyarakat enggan untuk mengurus akta jual beli di PPAT.

Pada tahun 2004 kemudian barulah terbentuk Provinsi Sulawesi Barat dari hasil pemekaran Provinsi Sulawesi Selatan, dengan Kabupaten Mamuju sebagai ibu kotanya. Jual beli di bawah tangan masih terus berlanjut, dengan praktek hanya berupa kesepakatan antara penjual dan pembeli sementara pada saat itu Kabupaten Mamuju Tengah masih bergabung dengan Kabupaten Mamuju, untuk menghadap PPAT masih cukup jauh dan akses jalan darat masih kurang baik sehingga menyulitkan baik penjual dan pembeli untuk menghadap PPAT.

Kedua, saat itu harga tanah relatif masih murah dan jarang sekali ada yang berminat untuk membelinya, sehingga penjual maupun pembeli tidak mau direpotkan dengan urusan pembuatan akta jual beli di PPAT. Disisi lain masyarakat tidak memahami bahwa untuk mengalihkan suatu hak atas tanah diperlukan akta otentik yang dibuat di hadapan PPAT.

Ketiga, terbatasnya pejabat pembuat Akta Tanah di daerah. Keempat, Ketidakmampuan ekonomi masyarakat membuat akta PPAT.

Praktek jual beli hak atas tanah di bawah tangan karena prosesnya yang mudah, cepat selesai, praktis dan biayanya lebih murah dibandingkan dengan jual beli hak atas tanah yang dilakukan di hadapan PPAT. Menurut Hastuti, faktor penyebab sering dilakukannya pembelian tanah yang belum atau tidak sekaligus dilaksanakan di hadapan PPAT antara lain: ${ }^{12}$

1. Masyarakat kurang paham atau bahkan ketidaktahuan dari si pelaku transaksi baik penjual maupun pembeli tanah mengenai ketentuan hukum yang berlaku;

2. Mula pertama atas dasar hanya karena saling percaya antara penjual dan pembeli dan ketidaktahuan atas hak-hak dan kewajiban selaku penjual dan pembeli tanah;

3. Tanah yang menjadi obyek jual beli belum belum dikonversi;

4. Belum mempunyai biaya untuk peralihan haknya atau bahkan juga belum mempunyai dana untuk membayar Pajak Penghasilan (PPh) maupun Bea Perolehan Tanah dan Bangunan (BPHTB);

5. Jenis tanahnya masih merupakan tanah pertanian (sawah/tegal), sedangkan yang dibeli hanya sebagian, sehingga harus

10 Ibid

11 Wawancara dengan Alimuddin (Kepala Desa Salugatta) 17 April di Kabupaten Mamuju Tengah, 2020.

12 Prancisca Romana Dwi Hastuti, (Juli - Desember 2015), Keabsahan Jual Beli Hak Atas Tanah Dibawah Tangan Di Desa Patihan Kecamatan Sidoharjo Kabupaten Sragen (Tinjauan Beberapa Kasus Terkait di Pengadilan Negeri di Surakarta), Jurnal Repertorium, Volume 2, Nomor 2. Hlm. 177-125. 
dimohon perubahan status tanah tersebut lebih dahulu menjadi tanah perumahan/ pekarangan;

6. Jenis tanahnya masih tanah pertanian, sedangkan pembeli bertempat tinggal di luar wilayah kecamatan letak tanah yang menjadi obyek jual beli atau bahkan di luar kabupaten atau propinsi, sehingga masih menunggu proses perpindahan penduduk bagi pembeli agar tidak melanggar ketentuan mengenai absentee, atau dalam hal demikian ditempuh jalan dimohon/diproses permohonan perubahan jenis tanah menjadi tanah perumahan lebih dahulu.

7. Guna memudahkan proses peralihan haknya dikarenakan pemilik tanah sudah meninggal dunia, sedangkan ahli warisnya berjumlah cukup banyak. Sebagian besar dari mereka sudah berusia lanjut dan bertempat tinggal jauh dari lokasi tanah yang dijual.

Akibat dari peralihan hak atas sertipikat tanah yang dilakukan dengan jual beli bawah tangan tersebut di antaranya adalah sertipikat hak atas tanah tidak dapat diproses balik nama pada kantor pertanahan, sertipikat hak atas tanah tidak dapat dijadikan jaminan kredit/pinjaman pada bank atau lembagalembaga pembiayaan dan banyaknya muncul kuasa-kuasa palsu dan kuasa mutlak sebagai akibat dari pihak penjual/pemilik awal sertipikat tidak diketahui lagi keberadaannya yang mana kuasa-kuasa tersebut tidak dapat digunakan di kemudian hari dan tidak dapat dijadikan dasar kepemilikan. ${ }^{13}$

PPAT mempunyai tugas yang penting dan strategis dalam penyelenggaraan pendaftaran tanah yaitu membuat akta peralihan hak atas tanah. Tanpa bukti berupa akta PPAT, para Kepala Kantor Pertanahan dilarang mendaftar perbuatan hukum yang bersangkutan. ${ }^{14}$

Fungsi dan peran PPAT sangat penting dalam pembuatan akta jual beli, termasuk hak milik atas satuan rumah susun bila terjadi kesepakatan dari 2 (dua) pihak dimana pihak penjual dan pembeli terhadap sebidang hak atas tanah atau hak milik atas satuan rumah susun. Akibat hukum yang terjadi dengan ditandatanganinya akta jual beli adalah bahwa sejak saat itu hak atas tanah menjadi milik pembeli dan uang yang akan dibayarkan oleh pembeli menjadi milik penjual. Pertukaran kepemilikan antara penjual dan pembeli tersebut di atas terjadi bersamaan pada saat ditandatanganinya akta jual beli. ${ }^{15}$

Penyelenggaraan pendaftaran tanah diperlukan PPAT sebagai salah satu pelaksanaan pendaftaran tanah dengan membuat akta PPAT, dimana akta PPAT merupakan salah satu sumber utama dalam rangka pemeliharaan data pendaftaran tanah. ${ }^{16}$

\footnotetext{
${ }^{13}$ Sulastiningsih, (Desember 2019), Peralihan Hak Atas Sertipikat Tanah Hak Milik Eks Transmigrasi yang Dilakukan Dengan Jual Beli Bawah Tangan (Studi Kasus Para Petani Sawit Di Kabupaten Kampar), Jurnal Lex Librum, Volume 6, Nomor 1. Hlm. 57-76.

${ }^{14}$ Boedi Harsono, (1995), Tugas dan Kedudukan Pejabat Pembuat Akta Tanah, Jurnal Hukum dan Pembangunan, Volume 25, Nomor 6. Hlm. 478.

15 Akur Nurasa dan Dian Aries Mujiburohman, (Novermber 2020), Buku Ajar Tuntunan Pembuatan Akta Tanah, Yogyakarta; STPN Press. Hlm. 63.

${ }^{16}$ Prawira, I. G. B. Y., \& Yoga, G. B. (2016), Tanggung Jawab PPAT terhadap Akta Jual Beli Tanah, Jurnal Ius, Volume 4, Nomor 1. Hlm. 69-77.
} 
Pemeliharaan data pendaftaran tanah adalah kegiatan pendaftaran tanah untuk menyesuaikan data fisik dan data yuridis dalam peta pendaftaran, daftar tanah, daftar nama, surat ukur, buku tanah, dan sertifikat dengan perubahan-perubahan yang terjadi kemudian. ${ }^{17}$

Ketiadaan akta PPAT menyebabkan peralihan hak atas tanah tidak dapat dilakukan, secara hukum adat peralihan di bawah tangan sah. Namun undang undang dan peraturan pelaksananya mengatur bahwa peralihan melalui jual beli mensyaratkan adanya akta PPAT. Dengan demikian seyogyanya ada peraturan perundang-undangan untuk mengaturnya tidak cukup dengan diskresi pejabat berwenang maupun menggunakan surat keterangan penguasaan fisik semata.

Karena ditakutkan apabila menggunakan surat keterangan penguasaan fisik akan menimbulkan sengketa hukum di kemudian hari. Hal inilah yang menyebabkan Kantor Pertanahan tidak menggunakan surat keterangan tersebut. hingga saat ini belum ada aturan yang mengatur secara tegas peralihan di bawah tangan, setiap Kantor Pertanahan menggunakan cara yang berbeda-beda dalam menyelesaikan peralihan di bawah tangan.

Penyelesaian Peralihan Hak Atas Tanah di Bawah Tangan di Mamuju Tengah
Pada hakikatnya hak tanah merupakan hubungan hukum antara subjek hak dengan tanah, dimana hubungan tersebut memperoleh perlindungan hukum, tujuan dari hak atas tanah adalah untuk memberikan kepastian hukum terhadap hubungan hukum tersebut. ${ }^{18}$ Untuk mewujudkan kepastian dan perlindungan hukum, maka penguasaan dan pemilikan tanah harus didaftarkan, untuk mengetahui siapa pemiliknya, luasnya, haknya, penggunaannya. Kemudian kepastian hukum tentang subjek dan objek hak. Pendaftaran tanah menghasilkan sertipikat sebagai tanda bukti hak atas tanah.

Pada proses pendaftaran tanah dikenal peralihan hak atas tanah yaitu berpindahnya hak kepada orang lain. Peralihan hak atas tanah dilakukan melalui jual beli, tukar menukar, hibah, pemasukan dalam perusahaan dan perbuatan hukum pemindahan hak lainnya sebagaimana diatur dalam Pasal 37 ayat (1) Peraturan Pemerintah Nomor 24 Tahun 1997 tentang Pendaftaran Tanah. Dalam proses peralihan hak atas tanah kecuali pemindahan hak melalui lelang, hanya dapat didaftarkan jika dibuktikan dengan akta yang dibuat oleh PPAT. Pada kasus penelitian ini adalah peralihan hak atas tanah melalui jual beli di bawah tangan atas tanah transmigrasi tanpa akta PPAT.

\footnotetext{
17 Akur Nurasa dan Dian Aries Mujiburohman, (2020), Buku Ajar Pemeliharaan Data Pendaftaran Tanah, Yogyakarta; STPN Press. Hlm. 1.

${ }^{18}$ Dian Aries Mujiburohman, (2016), Problematika Pengaturan Tanah Negara Bekas Hak Yang Telah Berakhir, BHUMI: Jurnal Agraria dan Pertanahan, Volume 2, Nomor 2. Hlm. 158.
} 
Jual beli di bawah tangan dalam bentuk kuitansi atau perjanjian antara kedua belah pihak dalam hukum adat dan KUH Perdata dianggap sah, namun belum menjamin kepastian hukum dan perlindungan hukum bagi pembeli. Karena dalam proses balik nama atas nama pembeli pada Kantor Pertanahan, surat jual beli bawah tangan tidak dapat dijadikan dasar untuk pendaftaran proses balik namanya.

Kantor Pertanahan mensyaratkan adanya akta PPAT dalam proses peralihan hak atas tanah. Apabila tidak ada akta PPAT, maka diperlukan penetapan atau putusan pengadilan yang telah berkekuatan hukum tetap. Bila menggunakan ketentuan Pasal 37 ayat 2 Peraturan Pemerintah Nomor 24 Tahun 1997 yang memberi kewenangan Kantor Pertanahan peralihan hak atas tanah tanpa PPAT memungkin akan ada sengketa tanah atau gugatan dikemudian hari. ${ }^{19}$

Permasalahan dalam melakukan pendaftaran tanah berdasarkan putusan pengadilan tidak hanya karena keengganan dan keraguan Kepala Kantor Pertanahan, serta adanya ketidakharmonisan peraturan perundang-undangan terkait pendaftaran tanah..$^{20}$
Ketentuan dalam Pasal 37 ayat 2 Peraturan Pemerintah Nomor 24 Tahun 1997 tentang Pendaftaran Tanah, memungkin peralihan tanpa akta PPAT, ketentuan tersebut menyatakan:

Dalam keadaan tertentu sebagaimana yang ditentukan oleh menteri, Kepala Kantor Pertanahan dapat mendaftarkan pemindahan hak atas bidang tanah hak milik, yang dilakukan di antara perorangan WNI yang dibuktikan akta yang tidak dibuat oleh PPAT, tetapi yang menurut Kepala Kantor Pertanahan tersebut kadar kebenarannya dianggap cukup untuk mendaftar pemindahan hak yang bersangkutan.

Ketiadaan akta PPAT dalam peralihan hak atas tanah atas jual beli di bawah tangan tanah transmigrasi disebabkan pemilik yang tertera dalam sertipikat sudah tidak diketahui keberadaannya, bahkan bila dirunut penguasaan atas sertipikat sudah ada yang sampai puluhan kali hingga sampai ke tangan pembeli yang sekarang menguasai sertipikat tersebut. Ketidakhadiran pemilik yang namanya tertera dalam sertipikat menjadi hambatan dalam pembuatan akta otentik di hadapan PPAT. ${ }^{21}$

Menurut Alimuddin sebagai Kepala Desa Salugatta, bahwa hanya sedikit warga yang melaporkan kepadanya apabila telah terjadi suatu transaksi jual beli di bawah tangan. Menurutnya jual beli tanah di wilayahnya

\footnotetext{
${ }^{19}$ Wawancara dengan M. H. Bakri (Kepala Kantor Pertanahan Kabupaten Mamuju Tengah) 24 April di Kabupaten Mamuju Tengah, 2020.

${ }^{20}$ Danar Fiscusia Kurniaji, (July-September 2016), Pendaftaran Hak Atas Tanah Berdasarkan Putusan Pengadilan, Fiat Justisia Journal of Law, Volume 10, Nomor 3. Hlm. 433-455.

${ }^{21}$ Wawancara dengan H. Kunnu Sila dan Hj. Dg. Caya (Pembeli Hak Atas Tanah Transmigrasi) 21 April di Kabupaten Mamuju Tengah, 2020.
} 
memang kebanyakan dilakukan dengan cara di bawah tangan dikarenakan pada waktu transaksi yang dilakukan yaitu antara sekitar tahun 1991 sampai dengan tahun 2003, saat itu wilayah Provinsi Sulawesi Barat belum terbentuk dan masih bergabung dengan wilayah Provinsi Sulawesi Selatan dengan ibu kota Makassar sebagai sentral pemerintahan, jarak yang terlampau jauh dari kota, membuat masyarakat enggan untuk mengurus akta PPAT. $^{22}$

Hal senada juga disampaikan oleh Kepala Unit Bidang Transmigrasi Kabupaten Mamuju Tengah Musafiruddin Said, menjelaskan bahwa jual beli di bawah tangan atas tanah transmigrasi merupakan masalah yang membutuhkan perhatian dan diperlukan adanya sinergitas dari instansi terkait, khususnya Pemerintah Daerah dan Kantor Pertanahan.

Maraknya jual beli di bawah tangan disebabkan para transmigran ingin kembali ke daerah asalnya dan tidak seriusnya menggarap tanah pertanian dan perkebunan, padahal para transmigran telah dilakukan pembinaan, telah diberikan jatah hidup selama satu tahun yang kemudian selama lima tahun ke depan transmigran akan dibina agar dapat hidup mandiri dari hasil lahan yang diberikan. ${ }^{23}$

Lebih lanjut Musafiruddin Said menyatakan koordinasi telah dilakukan dalam bentuk kerja sama untuk menyelesaikan masalah-masalah tanah transmigrasi, diantaranya bentuk Perjanjian Kerja Sama (PKS) antara Pemerintah Daerah Provinsi dengan Kantor Wilayah Pertanahan untuk menginventarisasi penguasaan, pemilikan, penggunaan dan pemanfaatan tanah $(\mathrm{P} 4 \mathrm{~T})$ di lokasi transmigrasi yang terindikasi masalah dalam rangka percepatan penyelesaian masalah dan sebagian Peserta Transmigrasi masih belum secara optimal mengusahakan atau mengelola tanah yang menjadi bagiannya dan ada sebagian yang ditelantarkan (PKS Nomor 036/PKS/VI/2020).

Kemudian ditindaklanjuti oleh PKS Nomor AT.02.02/336-79.06/VI/2020 antara Dinas Transmigrasi dan Tenaga Kerja Kabupaten Mamuju Tengah dengan Kantor Pertanahan salah satunya adalah banyaknya subyek dan obyek transmigrasi yang sudah tidak sesuai lagi (sudah beralih atau berpindah di bawah tangan).

Selain dibuktikan dengan akta yang dibuat oleh PPAT, peralihan hak atas tanah juga bisa terjadi karena Putusan Pengadilan yang telah memperoleh kekuatan hukum tetap dan dengan Penetapan Ketua Pengadilan yang mengakibatkan terjadinya perubahan pada data mengenai bidang tanah yang sudah didaftar. Bagi masyarakat salah satu syarat penetapan atau keputusan pengadilan untuk

\footnotetext{
${ }^{22}$ Wawancara dengan Alimuddin (Kepala Desa Salugatta) 17 April di Kabupaten Mamuju Tengah, 2020.

${ }^{23}$ Wawancara Musafiruddin Said (Kepala Unit Bidang Transmigrasi Kabupaten Mamuju Tengah) 29 April di Kabupaten Mamuju Tengah, 2020.
} 
balik nama sertipikat akan sulit dilakukan karena akan memerlukan biaya yang tidak sedikit, disisi lain pemahaman dan pengetahuan masyarakat mengenai konsep penyelesaian masalah melalui jalur pengadilan masih relatif kurang, demikian juga faktor jarak yang jauh dari Kantor Pengadilan.

Persepsi masyarakat melalui putusan pengadilan itu rumit, lama dan mahal, hal ini ditanggapi oleh Staf Ahli Kejaksaan Tinggi Negeri Provinsi Sulawesi Barat. Bila penyelesaian melalui putusan pengadilan dalam penyelesaian masalah jual beli hak atas tanah transmigrasi, pengadilan telah memberikan kemudahan baik pengurusan, persyaratan maupun informasi yang dibutuhkan oleh masyarakat. Umumnya kesulitan pada kelengkapan berkas-berkas yang dibutuhkan oleh pengadilan. ${ }^{24}$

Secara garis besar pendaftaran tanah berdasarkan putusan pengadilan di atur dalam Pasal 55 Peraturan Pemerintah Nomor 24 Tahun 1997 tentang Pendaftaran Tanah yaitu:
a. Panitera
Pengadilan
wajib

memberitahukan kepada Kepala Kantor

Pertanahan mengenai isi semua putusan

Pengadilan yang telah memperoleh

kekuatan hukum tetap dan putusan Ketua

Pengadilan yang mengakibatkan terjadinya perubahan pada data mengenai bidang tanah yang sudah didaftar atau satuan rumah susun untuk dicatat pada buku tanah yang bersangkutan dan sedapat mungkin pada sertipikatnya dan daftar-daftar lainnya.

b. Pencatatan dapat dilakukan juga atas permintaan pihak yang berkepentingan, berdasarkan salinan resmi putusan pengadilan yang telah memperoleh kekuatan hukum tetap atau salinan putusan Ketua Pengadilan yang bersangkutan yang diserahkan olehnya kepada Kepala Kantor Pertanahan.

c. Pencatatan hapusnya hak atas tanah, hak pengelolaan dan hak milik atas satuan rumah susun berdasarkan putusan Pengadilan dilakukan setelah diperoleh surat keputusan mengenai hapusnya hak yang bersangkutan dari Menteri atau Pejabat yang ditunjuknya.

Akta di bawah tangan mempunyai kekuatan pembuktian sempurna seperti akta otentik sepanjang tanda tangan dan isi yang terdapat dalam akta tersebut diakui oleh para pihak yang membuat akta tersebut. ${ }^{25}$ Namun karena pihak yang menjual tidak diketahui keberadaannya, hal ini yang tidak dapat dilakukan pendaftaran tanahnya. Apabila pihak yang menjual diketahui maka tetap

\footnotetext{
${ }^{24}$ Wawancara Irvan Paham PD Samosir (Staf Ahli Kejaksaan Tinggi Negeri Provinsi Sulawesi Barat) 19 Juni di Kabupaten Mamuju, 2020.

${ }^{25}$ Richard Cisanto Palit, (2015), Kekuatan Akta di Bawah Tangan Sebagai Alat Bukti di Pengadilan, Lex Privatum, Volume 3, Nomor 2. hlm. 142.
} 
mengulang terlebih dahulu melakukan transaksi jual beli di hadapan PPAT untuk mendapatkan akta jual beli yang merupakan salah satu persyaratan pendaftaran peralihan hak atas tanah.

Dalam ketentuan Pasal 39 PP Nomor 24 Tahun 1997 disebutkan bahwa PPAT menolak membuat akta jika:

a. Mengenai bidang tanah yang sudah terdaftar kepadanya tidak disampaikan sertipikat asli hak yang bersangkutan atau

b. Mengenai bidang tanah yang belum didaftar, kepadanya tidak disampaikan;

c. Surat bukti hak atau Surat Keterangan Kepala Desa/Kelurahan yang menyatakan bahwa yang bersangkutan menguasai bidang tanah dan Surat Keterangan yang menyatakan bahwa bidang tanah yang bersangkutan belum bersertipikat dari Kantor Pertanahan atau untuk tanah terletak di jauh dari kedudukan Kantor Pertanahan dari pemegang hak yang bersangkutan dengan dikuatkan oleh kepala desa/Kelurahan;

d. Salah satu atau para pihak yang akan melakukan perbuatan hukum yang bersangkutan atau salah satu saksi tidak berhak atau tidak memenuhi syarat untuk bertindak demikian; atau

e. Salah satu pihak atau para pihak bertindak atas dasar suatu surat kuasa mutlak yang pada hakekatnya berisikan perbuatan hukum pemindahan hak; f. Untuk perbuatan hukum yang dilakukan belum diperoleh izin pejabat atau instansi yang berwenang, apabila izin tersebut diperlukan menurut peraturan-perundangundangan yang berlaku; atau

g. Objek perbuatan hukum yang bersangkutan sedang dalam sengketa mengenai data fisik dan atau data yuridisnya; atau

h. Tidak dipenuhinya syarat lain atau dilanggar larangan yang ditentukan dalam peraturan Perundang-undangan yang bersangkutan.

i. Penolakan untuk membuat akta tersebut diberitahukan secara tertulis kepada pihakpihak yang bersangkutan disertai alasannnya; Untuk memperoleh bukti yang kuat dan luas daya pembuktiannya, perbuatan hukum peralihan hak harus didaftarkan ke Kantor Pertanahan untuk dicatatkan pada buku tanah dan sertipikat yang bersangkutan.

Dengan dicatatkan peralihan hak pada sertipikatnya, diperoleh surat tanda bukti yang kuat. Karena peralihan hak atas tanah dan hak milik atas satuan rumah susun melalui jual beli, tukar menukar, hibah, pemasukan dalam perusahaan dan perbuatan hukum pemindahan hak lainnya, kecuali pemindahan hak melalui lelang, hanya dapat didaftarkan jika dibuktikan dengan akta yang dibuat oleh PPAT yang berwenang menurut ketentuan peraturan perundang-undangan yang berlaku. Meskipun jual beli yang di laksanakan secara 
di bawah tangan tidak bisa dilakukan peralihan haknya.

Menurut ketentuan Pasal 94 ayat (2) butir (h) PMNA/BPN Nomor 3 Tahun 1997 tentang Ketentuan Pelaksanaan Peraturan Pemerintah Nomor 24 Tahun 1997 tentang Pendaftaran Tanah, menegaskan tentang perubahan data yuridis berupa perubahan data pendaftaran tanah berdasarkan putusan pengadilan atau putusan Ketua Pengadilan yang telah berkekuatan hukum tetap, maka putusan pengadilan tersebut dapat dijadikan dasar peralihan hak atas tanah yang kemudian oleh Kepala Kantor Pertanahan Kabupaten/Kota setempat untuk dicatat dalam buku Tanah dan dilakukan perubahan nama dalam sertipikat dari pemilik tanah yang lama kepada pemilik tanah yang baru.

Dalam hal pendaftaran akta yang setiap adanya perubahan-perubahan itu akan dituangkan ke dalam akta, selanjutnya merupakan surat tanda buktinya, kemudian perubahannya dicatat pada buku tanah dan sertipikat hak yang bersangkutan, berdasarkan data yang dimuat dalam akta perubahannya.

Dalam hal peralihan hak atas tanah melalui putusan pengadilan hanya dapat didaftarkan kepada Kantor Pertanahan jika dibuktikan melalui Salinan Putusan yang dibuat oleh Pengadilan Negeri. Permohonan pendaftaran peralihan hak atas tanah yang diperoleh melalui Putusan Pengadilan diajukan oleh pemohon atau kuasanya kepada Kepala Kantor Pertanahan dengan melampirkan dokumen-dokumen sebagai berikut:

1. Formulir permohonan yang sudah diisi dan ditandatangani pemohon atau kuasanya di atas materai cukup.

2. Surat Keputusan Pengadilan.

3. Sertipikat asli.

4. Fotocopy identitas diri pemenang putusan pengadilan dan atau kuasanya

5. Surat Kuasa apabila permohonan dikuasakan.

6. Foto copy SPPT PBB tahun berjalan yang telah dicocokkan dengan aslinya oleh petugas loket dan penyerahan bukti SSB (BPHTB), bukti SSP/PPH dan bukti bayar uang pemasukan (pada saat pendaftaran hak)

Setelah semua persyaratan tersebut lengkap, pemohon bisa langsung mendaftarkan permohonan peralihan hak melalui putusan pengadilan, dengan menyerahkan berkas permohonan tersebut di loket pendaftaran kemudian akan diproses sampai selesai, sebagaimana diatur dalam Standar Pengaturan Operasional Pelayanan Pertanahan (SPOPP), Peraturan Kepala Badan Pertanahan Nasional Republik Indonesia Nomor 1 Tahun 2010 tentang Standar Pelayanan dan Pengaturan Pertanahan.

Namun demikian, ada beberapa Kepala Kantor Pertanahan seperti di Kabupaten Buton membuat sebuah diskresi atau kebijakan menyikapi permasalahan tersebut dengan melihat ketentuan dalam Pasal 37 ayat 
(2) Peraturan Pemerintah Nomor 24 Tahun 1997, kadar kebenarannya dianggap cukup untuk mendaftarkan pemindahan hak yang bersangkutan yaitu dengan diperkuat oleh Berita Acara Hasil Penelitian Data Yuridis dan Data Fisik Tanah dalam peninjauan lapangan. ${ }^{26}$

\section{KESIMPULAN}

Berdasarkan hasil pembahasan yang telah diuraikan dapat ditarik kesimpulan sebagai berikut:

Pertama, jual beli di bawah tangan tanah transmigrasi yang sudah bersertipikat menurut hukum Adat dan KUH Perdata adalah sah sepanjang terpenuhi unsur sahnya perbuatan jual beli, namun status keabsahan jual beli tanpa adanya akta otentik yang dibuat oleh PPAT dikategorikan lemah dan belum sempurna.

Kedua, mekanisme penyelesaian peralihan hak atas tanah untuk perubahan data yuridis dan fisiknya hanya dapat dilakukan dengan penetapan/keputusan pengadilan, jika tidak ada akta yang dibuat PPAT. Implementasi Pasal 37 Ayat (2) PP Nomor 24 Tahun 1997 yang memberi wewenang Kantor Pertanahan menilai kadar kebenaran suatu alas hak atau syarat dalam bentuk kuitansi atau hanya perjanjian antara kedua belah pihak tidak dapat diterapkan dengan alasan ditakutkan akan muncul sengketa di kemudian hari. Maka penyelesaiannya hanya melalui jalan penetapan/putusan pengadilan.

\section{DAFTAR PUSTAKA}

\section{Jurnal}

Asta Tri Setiawan, Sri Kistiyah, \& Rofiq Laksamana, (2021), Problematika Keabsahan Jual Beli Tanah di Bawah Tangan Tanah di Kawasan Transmigrasi, Tunas Agraria, Volume 4, Nomor 1.

Boedi Harsono, (1995), Tugas dan Kedudukan Pejabat Pembuat Akta Tanah, Jurnal Hukum dan Pembangunan, Volume 25, Nomor 6.

Danar Fiscusia Kurniaji, (July-September 2016), Pendaftaran Hak Atas Tanah Berdasarkan Putusan Pengadilan, Fiat Justisia Journal of Law, Volume 10, Nomor 3.

Dian Aries Mujiburohman, (2016), Problematika Pengaturan Tanah Negara Bekas Hak Yang Telah Berakhir, BHUMI: Jurnal Agraria dan Pertanahan, Volume 2, Nomor 2.

), (April, 2018), Menyoal Penafsiran Tanah Terlantar, Jurnal Yudisial, Volume 11 Nomor 1.

Nur Hayati, (2016), Peralihan Hak Dalam Jual Beli Hak Atas Tanah: Suatu Tinjauan Terhadap Perjanjian Jual Beli dalam Konsep Hukum Barat dan Hukum Adat dalam Kerangka Hukum Tanah Nasional, Lex Jurnalica, Volume 13, Nomor 3.

Prancisca Romana Dwi Hastuti, (Juli Desember 2015), Keabsahan Jual Beli Hak Atas Tanah Dibawah Tangan Di Desa Patihan Kecamatan Sidoharjo Kabupaten Sragen (Tinjauan Beberapa Kasus Terkait di Pengadilan Negeri di Surakarta), Jurnal Repertorium, Volume 2, Nomor 2.

\footnotetext{
${ }^{26}$ Asta Tri Setiawan, Sri Kistiyah, \& Rofiq Laksamana, (2021), Problematika Keabsahan Jual Beli Tanah di Bawah Tangan Tanah di Kawasan Transmigrasi, Tunas Agraria, Volume 4, Nomor 1. Hlm. 22-39.
} 
Prawira, I. G. B. Y., \& Yoga, G. B. (2016), Tanggung Jawab PPAT terhadap Akta Jual Beli Tanah, Jurnal Ius, Volume 4, Nomor 1.

Richard Cisanto Palit, (2015), Kekuatan Akta di Bawah Tangan Sebagai Alat Bukti di Pengadilan, Lex Privatum, Volume 3, Nomor 2.

Sulastiningsih, (Desember 2019), Peralihan Hak Atas Sertipikat Tanah Hak Milik Eks Transmigrasi yang Dilakukan Dengan Jual Beli Bawah Tangan (Studi Kasus Para Petani Sawit Di Kabupaten Kampar), Jurnal Lex Librum, Volume 6, Nomor 1.

WH. Legiani, Lestari RY., Haryono, (2018), Transmigrasi dan Pembangunan di Indonesia: Studi Deskriptif Sosiologi Kependudukan dan Pembangunan, Jurnal Hermeneutika, Volume 4, Nomor 1.

\section{Buku}

Adrian Sutedi, (2010), Peralihan Hak Atas Tanah dan Pendaftarannya, Cetakan IV, Jakarta; Sinar Grafika.

Ahmad Fauzie Ridwan, (1982), Hukum Tanah Adat, Jakarta; Dewaruci Press.

Akur Nurasa dan Dian Aries Mujiburohman, (2020), Buku Ajar Pemeliharaan Data Pendaftaran Tanah, Yogyakarta; STPN Press.

Akur Nurasa dan Dian Aries Mujiburohman, (Novermber 2020), Buku Ajar Tuntunan Pembuatan Akta Tanah, Yogyakarta; STPN Press.

Maria SW. Sumardjono, (2001), Kebijakan Pertanahan Antara Regulasi dan Implementasi, Jakarta; Buku Kompas.

S.P Florianus Sangsun, (2008), Tata Cara Mengurus Sertipikat Tanah, Jakarta; Visi Media. 